Journal of Maternal and Child Health (2019), 4(6): 516-521

https://doi.org/10.26911/thejmch.2019.04.06.12

\title{
Associations between Education, Knowledge, Attitude, and Maternal Intention on Antenatal Care Visit
}

\author{
Polma Ria Metawati Panjaitan, Heru Santosa, Surya Utama
}

Masters Program in Public Health, Universitas Sumatera Utara

\begin{abstract}
Background: Good quality of health care is important for maternal and infants health. Regular antenatal visit can assist in identifying and reducing risks of mother and infant during pregnancy. This study aimed to examine the associations between education, knowledge, attitude, and maternal intention on antenatal care (ANC) visit.

Subjects and Method: A cross sectional study was carried out at Ridos hospital, Medan, North Sumatera, in 2017. A sample of 89 pregnant women was selected by accidental sampling. The dependent variable was ANC visit. The independent variables were education, knowledge, and attitude. The data were collected by questionnaire and analyzed by linear multiple regression.

Results: Maternal intention to do ANC visit increased with high education $(b=0.36 ; p=0.001)$, knowledge $(b=0.48 ; p=0.001)$, and attitude $(b=0.24 ; p=0.001)$.

Conclusion: Maternal intention to do ANC visit increased with high education, knowledge, and attitude.
\end{abstract}

Keywords: antenatal care, pregnant women

Correspondence:

Polma Ria Metawati Panjaitan. Masters Program in Public Health, Universitas Sumatera Utara. Jl. Universitas 21, Medan 20155, North Sumatera. Email: happypolma@yahoo.com. Mobile: o81370801033.

\section{BACKGROUND}

The target of Maternal Mortality Rate (MMR) in the Global Millennium Development Goals (MDGs) program that ended in 2015 has not achieved. This is likely caused by: (1) inadequate quality of maternal health services; (2) unhealthy condition of pregnant women (handling complications), namely anemia, diabetes, hypertension, malaria; (3) 4-T namely: too young, too old, pregnancy interval $<2$ years and too many children; and (4) other determinant factors such as postpartum hemorrhage. It can be minimized by good Antenatal Care (ANC) implementation (Strategic Plan of Ministry of Health, 2015-2019).

Based on the Indonesian Demographic and Health Survey (IDHS) in 2012, the Maternal Mortality Rate in Indonesia is still high at 359 per 100,000 live births.
This is not in accordance with the $5^{\text {th }}$ Global Millennium Development Goals (MDGs) target in reducing the Maternal Mortality Rate (MMR) to 102 per 100,000 live births in 2015. In other words, the Global MDGs target has not achieved (Data Center and Information of Ministry of Health RI, 2014).

Meanwhile, MMR in North Sumatra is still high, including: (1) 228/100,00o live births in 2016; (2)175/100,000 live births in 2015; and (3) 152/100,000 live births in 2014, and $187 / 100,000$ live births in Medan in 2014 (http://www.sumutprov.go.id).

Based on the result of the Preliminary Survey (January-April 2017) at Ridos Hospital in Medan, the Antenatal Care (ANC) examination increased, including: (1) in 2014, there were 698 people and 376 of 
them did ANC repeat visit; (2) in 2015, there were 769 people and 455 of them did ANC repeat visit; and (3) in 2016, there were 889 people and 498 of them did ANC repeat visit. Based on these data, the ANC repeat visit in patients at Ridos Hospital is still low.

The low level of intention to do ANC examination repeat visit at Ridos Medan General Hospital occurred due to the association between individual characteristics (education, knowledge, and attitude) on the intention to do ANC examination repeat visit.

This study aimed to analyze the association between education, knowledge, and attitude on ANC repeat visit.

\section{SUBJECTS AND METHOD \\ 1. Study Design \\ This study was an explanatory research design which aimed to explain the effects of the individual characteristics (education, knowledge, and attitude) on the intention to do ANC repeat visit at Ridos Hospital in 2017. This study was conducted at Ridos Hospital, Medan. The field study was carried out in March, 2018.}

\section{Population and Sample}

The population in this study was all pregnant women who did ANC visit at Ridos Hospital, Medan. Based on the data from Ridos Hospital, Medan, in 2017, the number of pregnant women undergoing ANC was 889 people. Based on the sampling formula, the number of sample was 89 people. This study used accidental sampling.

\section{Study Variables}

The dependent variable was intention to do ANC repeat visit. The independent variables were education, knowledge, and attitude.

\section{Operational Definition of Variables}

Intention to do ANC repeat visit was the intention or plan of pregnant women to do ANC repeat visit. The data were obtained from questionnaires. The measurement scale was continuous.

Education was the highest level of formal education ever taken by pregnant women. The data were obtained from questionnaires. The measurement scale was categorical.

Knowledge was everything that was known by pregnant women about the ANC examination included the understanding, purpose, benefits, and the number of ANC visits. The data were obtained from questionnaires. The measurement scale was continous.

Attitude was the reaction or process of a pregnant woman to act or do a repeat visit of the ANC examination. The data were obtained from questionnaires. The measurement scale was continous.

\section{Data Analysis}

The data were analyzed univariately, bivariately, and multivariately. The association between education, knowledge, and attitude of pregnant women on the maternal intention to do ANC repeat visit were analyzed by multiple linear regression.

\section{RESULTS \\ 1. Sample characteristics \\ Table 1 showed sample characteristics. Table 1 showed that educational back- ground of pregnant women was dominated by low level of education which was 40 pregnant women (44.9\%). Table 2 showed distribution of maternal knowledge on ANC.}

Table 3 showed characteristics of maternal attitude. Table 3 showed that $75.3 \%$ of pregnant women had positive attitude on ANC visit.

Table 4 showed characteristics of maternal intention on ANC visit. Table 4 showed that $59.6 \%$ of pregnant women had strong intention to do ANC visit. 
Journal of Maternal and Child Health (2019), 4(6): 516-521

https://doi.org/10.26911/thejmch.2019.04.06.12

Table 1. Sample characteristics by education

\begin{tabular}{lcc}
\hline \multicolumn{1}{c}{ Characteristics } & n & \% \\
\hline Did not graduate from Elementary School & 9 & 10.1 \\
Elementary School & 13 & 14.6 \\
Junior High School & 18 & 20.2 \\
Senior High Schoold & 28 & 31.5 \\
Academy & 13 & 14.6 \\
Bachelor & 8 & 9.0 \\
\hline
\end{tabular}

Table 2. Sample characteristics by knowledge about ANC

\begin{tabular}{lcccccc}
\hline \multirow{2}{*}{\multicolumn{1}{c}{ Variables }} & \multicolumn{6}{c}{ Categories } \\
\cline { 2 - 7 } & \multicolumn{2}{c}{ Poor } & \multicolumn{2}{c}{ Fair } & \multicolumn{2}{c}{ Good } \\
\cline { 2 - 7 } & $\mathbf{N}$ & $\mathbf{\%}$ & $\mathbf{N}$ & $\mathbf{\%}$ & $\mathbf{n}$ & $\mathbf{\%}$ \\
\hline Knowledge & 6 & 6.7 & 56 & 62.9 & 27 & 30.3 \\
a. Definition of ANC & 35 & 39.3 & 18 & 20.2 & 36 & 40.4 \\
b. Purpose of ANC & 26 & 29.2 & 34 & 38.2 & 29 & 32.6 \\
c. Function of ANC & 34 & 38.2 & 23 & 25.8 & 32 & 36.0 \\
d. Definition of ANC visit & 45 & 50.6 & 24 & 27.0 & 20 & 22.5 \\
e. Purpose of ANC visit & 37 & 41.6 & 33 & 37.1 & 19 & 21.3 \\
f. Number of ANC visit & 41 & 46.1 & 26 & 29.2 & 22 & 24.7 \\
\hline
\end{tabular}

Table 3. Attitude of pregnant women

\begin{tabular}{lccc}
\hline & Categories & n & \% \\
\hline Negative & & 22 & 24.7 \\
Positive & 67 & 75.3 \\
\hline
\end{tabular}

Table 4. Maternal intention on ANC visit

\begin{tabular}{lcc}
\hline Category & n & \% \\
\hline Low & 36 & 40.4 \\
High & 53 & 59.6 \\
\hline
\end{tabular}

\section{Multivariate Analisys}

Table 5 shows the results of the multiple linear regression analysis. Table 5 shows that the maternal intention to do ANC visit

Table 5. Multiple Linear Regression

\begin{tabular}{lcc}
\hline Independent Variable & b & p \\
\hline Knowledge & 0.48 & 0.001 \\
Education & 0.36 & 0.001 \\
Attitude & 0.24 & 0.001 \\
Constanta & -2.66 & $<0.001$ \\
R Square $=57 \%$ & & \\
\hline
\end{tabular}

increased with knowledge $(\mathrm{b}=0.48 ; \mathrm{p}=$ o.001), education $(b=0.36 ; p=0.001)$, and attitude $(b=0.24 ; p=0.001)$.

\section{DISCUSSION}

\section{Effects of Education on Maternal intention to do ANC visit}

The results of this study indicated that education had a positive effect on maternal intention to do ANC visit. The higher the education of pregnant women, the higher intention to do ANC visit.

This is consistent with Manurung's study (2015) which showed that there is an association between education and ANC visit. Mothers with higher education are 4.26 times more likely to take advantage of 
ANC visit compared to mothers with low education.

Rahman et al. (2016) stated that secondary education and above increased the likelihood of ANC visits $\geq 4$ times by 3.65 times.

Education is one of the important elements that will encourage the individual so that it can affect one's situation. With a higher level of education, it is expected that knowledge or information about the utilizetion of health services will be better. Health knowledge will affect one's behavior as a medium-term result of the education obtained. Health behavior will affect the improvement of public health indicators as a result of health education (Green-away et al., 2012; Emmanuel et al., 2013; Silva et al., 2018).

Muyunda et al. (2016) stated that high maternal education is associated with an optimal ANC visit in women of childbearing age in Zambia.

\section{Effect of Knowledge on Maternal intention to do ANC visit}

The results of this study indicated that knoledge increases the interest of maternal intention to do ANC visit.

The results showed that the majority of pregnant women (62.9\%) had good knowledge about the benefits of ANC. Pregnant women with low knowledge about ANC tend to not do ANC visit.

The results of this study indicated that one third of pregnant women (30.3\%) have good categorized knowledge about ANC visit.

A study by Kazwa et al. (2018) showed that knowledge of pregnant women has a positive association with the regularity of ANC visit. Pregnant women with a lack of knowledge about the benefits and schedule of ANC cause them to not do regular pregnancy checks. Ogunba and Abiodun's study (2017) showed that the knowledge of pregnant women affects the behavior of pregnant women in doing ANC.

A study by Patel et al. (2016) conducted in Pune, Maharashtra, India showed that the knowledge of pregnant women increase the regularity of ANC visit ( $\mathrm{OR}=5.72 ; 95 \% \mathrm{CI}=3.6$ to $9.2 ; \mathrm{p}<0.001)$.

Lack of knowledge about the importance of ANC visit can cause maternal mortality. The low ANC visit decreases the quality of health during pregnancy and affects the success of the birth process (Nurachman, 2014).

A study by Creanga et al. (2016) in Kenya stated that regular ANC visit is useful for detecting health problems during pregnancy and preparing for safe delivery.

\section{Effect of Attitude on Maternal Intention to do ANC Visit}

The results of this study indicated that the attitude of pregnant women affect the intention in doing ANC visit. A positive attitude increases the intention of pregnant women to do ANC visit. 32.6\% of pregnant women had a positive attitude towards ANC visit. A positive attitude is indicated by the indicator that ANC visit need to be carried out to obtain information about maternal and infant health and recognize pregnancy danger signs.

The results of this study are in line with a study by Ogunba and Abiodun (2017) in Nigeria which stated that knowledge and attitudes of pregnant women are associated to ANC visit.

Negative attitude of pregnant women is indicated by the assumption that ANC visit may not be able to prevent complications during pregnancy (Akhtar et al., 2018). The results of this study are consistent with Djonis's (2015) study, which showed that there is an association between attitude and utilization of ANC services.

A study by Carvalho et al. (2014) showed that attitude is associated with the 
frequency of ANC visit. Pregnant women with a positive attitude will increase the frequency of ANC visit.

Attitude is a collection of feelings, beliefs and behavioral tendencies towards certain ideas, objects and groups / people. Attitude is a condition in a person that affects his behavior, for example adherence to paramedic recommendations. Feelings include two things, feeling happy or unhappy about something that can have a big effect on the determination of attitude (Kawungezi et al., 2015).

Attitude is a reflection of feelings of pleasure or displeasure towards objects that are determined by one's beliefs. The more positive aspects in the belief, the happier is the attitude object. On the contrary, the more negative aspects in the belief, there will be displeasure towards the attitude object. For example in the service process, the more positive things shown by health workers in providing services to patients, the more positive the patients so that they become happier with the health service (Kawungezi et al., 2015).

\section{AUTHOR CONTRIBUTION \\ Ria Metawati Panjaitan is the main author who plays a role in collecting and process- ing data analysis of the study. Heru Santosa examined the conceptual framework and methodology of the study. Surya Utama gave the suggestion related to the discussion.}

\section{FUNDING AND SPONSORSHIP}

This study used independent fund by the main researcher.

\section{CONFLICT OF INTEREST}

There is no conflict of interest.

\section{ACKNOWLEDGEMENT}

We thank the Ridos hospital, Medan, North Sumatera for giving permission to collect the data.

\section{REFERENCE}

Akhtar S, Hussain M, Majeed I, Afza M (2018). Knowledge attitude and practice regarding antenatal care among pregnant women in rural area of Lahore. Int. J. Soc. Sc. Manage. 5(3): 155-162. Doi: 10.3126/ijssm.v5i3.20604 .

Astini S, Siti SN (2011). Pengetahuan Ibu Hamil dan Motivasi Keluarga dalam Pelaksanaan Antenatal Care di Puskesmas Ujung Batu Riau, Riau: Pusat Penelitian dan Pengembangan Ilmu Keperawatan Fakultas Keperawatan Universitas Sumatera Utara.

Carvalho HDFP, Suryadhi NT, Wulandari LPL (2014). Relationship between education, knowledge, attitude, behavior and family support with antenatal care (ANC) Visit Frequency among Expectant Mothers in the Ermera District Timor Leste, 2013. Public Health and Preventive Medicine. 2(1): 22-27.

Creanga AA, Odhiambo GA, Odera B, Odhiambo BO, Desai M, Goodwin M, Laserson K, Goldberg H (2016). Pregnant women's intentions and subsequent behaviors regarding maternal and neonatal service utilization: Results from a cohort study in Nyanza Province, Kenya. PLoS ONE 11(9): e0162017. https://doi.org/10.1371/journal.pone.0162017.

Djonis (2015). Hubungan pengetahuan dan sikap ibu hamil dengan pemanfaatan antenatal care di puskesmas kampung dalam Pontianak. Jurnal Vokasi Kesehatan. 1(1): 23-27. https://ejournal.poltekkes-pontianak.ac.id/index.php/JVK/article/viewFile/6/4. 
Emmanuel NK, Gladys EN, Cosmas UU (2013). Consumer knowledge and availability of maternal and child health services: a challenge for achieving MDG 4 and 5 in Southeast Nigeria. BMC Health Services Research. 13: 53. http://www.biomedcentral.com/1472-6963/13/53.

Greenaway ES, Leon J, Baker DP (2012). Understanding the association between maternal education and use of health services in Ghana: Exploring the role of health knowledge. J Biosoc Sci. 44(6): 733-747. doi: 10.1017/So021932012000041.

Hastono SP (2006). Statistik Kesehatan. Jakarta: Raja Grafindo Persada.

Kaswa R, Rupesinghe GFD, Longo-Mbenza B (2018). Exploring the pregnant women's perspective of late booking of antenatal care services at Mbekweni Health Centre in Eastern Cape, South Africa. Afr J Prm Health Care Fam Med. 10(1): a130o. https://doi.org/10.4102/phcfm.v10i1.1300.

Kawungezi PC, AkiiBua D, Aleni C, Chitayi M, Niwaha A, Kazibwe A, Sunya E, Mumbere EW, et al. (2015). Attendance and utilization of antenatal care (ANC) services: Multi-center study in upcountry areas of Uganda. Open $\mathrm{J}$ Prev Med. 5(3): 132-142. doi: 10.4236/ojpm.2015.53016.

Kementerian Kesehatan Indonesia (2015). Profil Kesehatan Indonesia. Badan Penelitian \& Pengembangan Kementerian Kesehatan. Jakarta: Kementerian Kesehatan RI.

Manurung M (2015). Faktor yang berhubungan dengan kunjungan antenatal care pada ibu hamil di Puskesmas Padangmatinggi Kecamatan Padangsidimpuan Selatan Kota Padangsidimpuan, Medan: Pusat Penelitian dan Pengembangan Ilmu Kesehatan
Masyarakat, Fakultas Kesehatan Masyarakat, Universitas Sumatera Utara.

Muyunda B, Makasa M, Jacobs C, Musonda P, Michelo C (2016). Higher educational attainment associated with optimal antenatal care visits among childbearing women in Zambia. Front Public Health. 4:127. https://dx.doi.org/10.3389\%2Ffpubh.2016.00127.

Nurachman E (2014). Nutrisi Dalam Keperawatan. Jakarta: Agung Seto.

Ogunba BO, Abiodun OB (2017). Knowledge and attitude of women and its influence on antenatal care attendance in Southwestern Nigeria. J Nutr Health Sci. 4(2): 207.

Patel BB, Gurmeet P, Sinalkar DR, Pandya KH, Mahen A, Singh N (2016). A study on knowledge and practices of antenatal care among pregnant women attending antenatal clinic at a Tertiary Care Hospital of Pune, Maharashtra. Med J DY Patil Univ. 9(3): 354-362. Doi: 10.4103/o9752870.182507.

Rahman M, Rahman M, Tareque I, Ferdos J, Jesmin SS (2016). Maternal pregnancy intention and professional antenatal care utilization in Bangladesh: A Nationwide Population-Based Survey. PLoS One. 11(6): e015776o. https://dx.doi.org/10.1371\%2Fjournal.pone.0157760.

Silva FB, Gondim EC, Henrique NCP, Fonseca LMM, de Mello DF (2018). Educational intervention involving young mothers: gaining knowledge on childcare. Acta paul. Enferm. 31(1). http://dx.doi.org/10.1590/1982-0194201800006. 